\title{
MENJELASKAN BLACK BOX PERSON-ORGANIZATION FIT PADA MUNCULNYA KREATIVITAS KARYAWAN
}

\author{
Ilham Maulana Ardiansyah ${ }^{(1)}$ \\ Nury Ariani Wulansari ${ }^{(2)}$ \\ ${ }^{(1)(2)}$ Manajemen, Universitas Negeri Semarang, Semarang, Indonesia \\ e-mail: nuryariani@mail.unnes.ac.id
}

\begin{abstract}
ABSTRAK
Penelitian ini bertujuan untuk mengetahui pengaruh kesesuaian individu-organisasi pada kreativitas karyawan, serta menguji peran komitmen organisasi sebagai variabel mediasi yang dapat menjembatani hubungan antara kesesuaian individu-organisasi pada kreativitas karyawan. Populasi dalam penelitian ini adalah karyawan UMKM konfeksi di Kabupaten Jepara dengan jumlah sampel sebanyak 279 orang. Teknik yang digunakan dalam penentuan jumlah sampel yaitu simple random sampling. Metode analisis yang digunakan yaitu instrument (validitas dan reliabilitas), uji asumsi klasik, analisis deskriptif, analisis regresi, dan analisis Path. Analisis menggunakan program SPSS (Statistical Product and Service Solution) versi 21. Metode pengumpulan data dengan menggunakan wawancara, kuesioner dan studi literature. Hasil penelitian menunjukkan bahwa kesesuaian individu-organisasi berpengaruh positif pada kreativitas karyawan, kesesuaian individu-organisasi berpengaruh positif pada komitmen organisasi, komitmen organisasi berpengaruh positif pada kreativitas karyawan, serta kesesuaian individu-organisasi berpengaruh positif pada kreativitas karyawan dengan komitmen organisasi sebagai variabel mediasi. Jadi, secara keseluruhan hipotesis dierima.
\end{abstract}

Kata kunci: kesesuaian individu-organisasi, komitmen organisasional, kreativitas karyawan

\begin{abstract}
This study aims to determine the effect of person-organization fit on the mployee creativity, as well as testing the role of organizational commitment as a mediation variable that can bridge the relationship between person-organization fit on employee creativity. The population in this study are employees of SMEs confection in Jepara regency with a total sample of 279 peoples. The technique used in determining the number of samples is simple random sampling. The analytical methods used are instrument (validity and reliability), classical assumption test, descriptive analysis, regression analysis, and Path analysis. Analysis using SPSS (Statistical Product and Service Solution) version 21. Methods of data collection using interviews, questionnaires and literature studies. The result of the research shows that person-organization fit has positive effect on employee's creativity, person-organization fit has positive effect on organizational commitment, organizational commitment has positive effect on employee creativity, and person-organization fit have positive effect on employee creativity with organizational commitment as mediation variable. Thus, the overall hypothesis is accepted..
\end{abstract}

Keywords: person-organization fit, organizational commitment, employee creativity

\section{PENDAHULUAN}

Pada era globalisasi persaingan dalam dunia bisnis semakin ketat, adanya persaingan ini akan menimbulkan banyak bermunculan peluang baru dalam dunia bisnis (Faizan, 2014). Baru-baru ini terdapat teori yang mengatakan bahwa bekerja dalam strategi bisnis didorong untuk memiliki keunggulan sumber daya manusia dalam rangka mengembangkan keunggulan kompetitif (Becker dan Gerhart, 1996). Berdasarkan pandangan yang berbasis sumber daya (Barney, 1991), perusahaan hanya dapat berkembang dengan adanya dukungan dari keunggulan kompetitif, dengan cara menciptakan nilai yang jarang dimiliki oleh pesaing atau sulit untuk ditiru oleh perusahaan lain. Dalam sebuah penelitian perusahaan dikatakan memiliki keunggulan kompetitif, ketika perusahaan tersebut memiliki kelebihan dalam mempertahankan pelanggan serta mampu bertahan menghadapi persaingan (Collins dan Porter, 1985). Hasil analisis membuktikan bahwa kinerja usaha kecil signifikan pengaruhnya terhadap keunggulan bersaing usahausaha kecil (Handriani, 2011).

Beberapa penelitian terdahulu mengatakan, bahwa ketika perusahaan ingin mencapai keunggulan kompetitif maka perusahaan memerlukan kreativitas karyawan yang dimilikinya (Sousa dan Coelho, 2011). Karyawan yang kreatif dalam bekerja akan menghasilkan ide-ide baru serta produk, proses, dan pendekatan yang tepat (Shalley dan Gilson, 2004). 
Dalam penggunaan dan pengembangan ide kreatif akan memungkinkan perusahaan untuk merespon peluang, beradaptasi, tumbuh, dan bersaing dalam perubahan dunia (Sousa dan Coelho, 2011).

Terdapat beberapa contoh yang menunjukkan kreativitas dalam bidang barang dan jasa yang akhirnya menjadikan perusahaan sangat sukses. Contoh pertama, ketika Steve Wozniak menemukan micro-computer, yang merupakan bentuk dari kreativitas dalam pengembangan produk baru. Walt Disney yang menciptakan Disneyland, langkah tersebut merupakan kreativitas dari penciptaan bentuk hiburan yang baru dimana orang tua dan anak dapat melakukan aktivitas bersama. Di Indonesia sendiri, terdapat Nadiem Makarim pendiri dari GOJEK, dengan memanfaatkan kecanggihan teknologi mobile, GO-JEK berhasil merevolusi industri transportasi ojek dan bahkan meningkatkan fungsinya seperti pengiriman barang, pesan antar makanan, berbelanja dan berpergian di tengah kemacetan. Tirto Utomo pendiri Aqua yang menjual air mentah dalam kemasan, dimana saat itu minuman ringan berkabonasi seperti Cola Cola, Sprite, 7 Up, dan Green Spot sedang naik daun sehingga gagasan menjual air putih tanpa warna dan rasa, bisa dianggap sebagai gagasan gila. beberapa contoh tersebut merupakan kreativitas yang menciptakan bentuk baru dari produk barang dan jasa yang belum pernah ada sebelumnya.

Penelitian Zhou dan Shalley (2003) kreativitas dianggap sebagai penciptaan ide baru dan bermanfaat mengenai produk (products), layanan/ jasa (services), proses (processes), dan prosedur (procedures). Termasuk didalamnya solusi kreatif untuk masalah bisnis, strategi bisnis, atau perubahan dalam proses kerja. Ide dianggap baru jika ide tersebut tidak memiliki persamaan dengan yang lain (unik), dan ide dianggap berguna jika ide tersebut memiliki pontensi nilai langsung atau tidak langsung terhadap organisasi (Shalley et al., 2004).

Istilah kreativitas dan inovasi sering saling di pertukarkan dalam studi penelitian (Saraç et al., 2014). Inovasi merupakan bagian dari keunggulan kompetitif (Putri dan Yuniawan, 2016) sama halnya dengan kreativitas. Kreativitas dan inovasi saling berhubungan, tetapi memiliki perbedaan yang sangat jelas (Farabee, 2011). Kreativitas merupakan penciptaan ide baru yang bermanfaat pada skala yang lebih kecil, dan inovasi adalah penerapan dari ide baru yang bermanfaat pada skala yang lebih luas. Berdasarkan pernyataan tersebut dapat dikatakan bahwa ketika perusahaan yang ingin menjadi inovatif maka terlebih dahulu harus menanamkan kreativitas pada anggota organisasinya.

Kreativitas karyawan merupakan sebuah perilaku yang kompleks yang mencakup kemampuan intelekual dan sosial. Berbagai pendekatan dari keilmuan seperti psikologi sosial, teori kognitif, dan teori kepribadian memiliki kontribusi penting bagi penelitian tentang kreativitas (Saraç et al., 2014). Berdasarkan pendekatan psikologi sosial, kreativias adalah keadaaan sosial dan lingkungan secara bersamaan, hal ini menjelaskan bahwa adanya pengaruh dari keadaan antara individu dan lingkungan kerja yang mempengaruhi kreativitas karyawan. Pendapat tersebut juga didukung oleh Runco (2004) mengkategorikan kreativitas kedalam empat topik yang salah satunya adalah tekanan (press), yang menunjukkan adanya hubungan antara individu dan lingkungan.

Tingkat kesesuaian (Fit) antara individu dan lingkungan memiliki lima tingkatan (Kristof-brown et al., 2005). Satu, Person-Job Fit yaitu hubungan antara karakteristik individu dan pekerjaan atau tugas yang yang dilakukan dalam bekerja. Dua, PersonGroup Fit yaitu kesesuaian antara individu dan kelompok atau tim kerja. Tiga, Person-Supervisor Fit yaitu hubungan dyadic antara individu dan lainnya dalam lingkungan kerja. Empat, PersonOrganization Fit yaitu kesesuaian individuorganisasi secara keseluruhan. Dan terakhir, Person-Vacation Fit yaitu kesesuaian antara ketertarikan (interest) individu dengan individu lain pada sebuah pekerjaan. Diantara tingkat kesesuaian (Fit) tersebut, kesesuaian individu-organisasi (Person-Organization Fit) merupakan subjek yang paling banyak diteliti (Tugal dan Kilic, 2015).

Secara luas Kesesuaian individu-organisasi dianggap sebagai kesesuaian antara karyawan dan organisasi yang menaunginya (Santos, 2015). Kesesuaian individu-organisasi sekaligus menjadi tantangan terbesar yang dihadapi perusahaan dalam memastikan kinerja karyawan tetap stabil bahkan meningkat. Salah satu cara yang bisa dilakukan adalah dengan memastikan adanya kesesuaian antara nilai- nilai organisasi dengan karakteristik karyawan. Cable dan Judge (1995) mengungkapkan bahwa secara teori dan empiris menunjukkan bahwa individu dan organisasi akan sangat efektif ketika nilai (Value), kebutuhan (Need), ketertarikan (Interesting) antara keduanya sesuai. Maksud dari sesuai disini adalah kecocokan nilai individu dengan nilai organisasi (Person-Organization Fit), termasuk didalamnya komitmen, kepuasan, dan hak 
karyawan serta kinerja organisasi. Hal ini didukung oleh penemuan penelitian terdahulu yang menunjukkan bahwa karyawan memiliki tingkat kesesuaian lebih tinggi atau nilai yang sama dengan organisasi akan menghasilkan hubungan positif antara individu dan organisasi (Tugal dan Kilic, 2015). Hubungan positif tersebut tidak hanya menghasilkan dampak positif bagi organisasi namun terhadap individu juga.

Penelitian Edwards (2008) menyatakan bahwa Kesesuaian individu-organisasi merupakan hubungan antara karakteristik individu dan lingkungan sehingga mampu mempengaruhi perilaku karyawan, karena ketika karyawan bekerja di lingkungan dimana terdapat nilai yang sesuai dengan dirinya maka karyawan akan berperilaku positif (Thomas, 2013). Diantara perilaku positif yang dihasilkan oleh kesesuaian individu-organisasi, salah satunya adalah kreativitas karyawan. Jadi, ketika karyawan memiliki tingkat kesesuaian individuorganisasi yang tinggi maka karyawan tersebut akan memiliki perilaku yang lebih kreatif (Jin, 2015).

Penelitian ini dilakukan berdasarkan tiga alasan. Alasan pertama, adanya perbedaan pandangan mengenai hubungan antara Kesesuaian individuorganisasi terhadap kreativitas karyawan. Dalam beberapa penelitian menganggap bahwa Kesesuaian individu-organisasi memiliki hubungan positif terhadap kreativitas karyawan (Saraç et al., 2014; Jin, 2015). Pandangan ini menganggap bahwa ketika tingkat kesesuaian antara individu dan lingkungan tinggi maka kreativitas karyawan akan meningkat. Namun, di sisi lain ada pendapat yang menyatakan bahwa Kesesuaian individu-organisasi dapat menjadi penghalang atau penghambat bagi kreativitas karyawan (Farabe, 2011), karena ketika karyawan memiliki tingkat kesesuaian nilai yang tinggi dengan organisasi maka karyawan tersebut akan bekerja sesuai dengan nilai organisasi sehingga dan tidak berusaha untuk berperilaku kreatif. Dalam penelitian ini peneliti berfokus pada pendapat yang menyatakan bahwa kesesuaian antara individu dan organisasi memiliki hubungan positif dengan kreativitas karyawan, karena penelitian sebelumnya banyak ditemukan hasil yang positif. Alasan kedua, penelitian terdahulu melakukan pengujian secara langsung mengenai hubungan antara kesesuaian individuorganisasi dan kreativitas. Penelitian ini, mencoba untuk menelitian hubungan antara kesesuaian individu-organisasi dan kreativitas dengan memasukan variabel pemediasi komitmen organisasional. Beberapa penelitian ditemukan bahwa komitmen organisasional merupakan memiliki variabel prediktor yang kuat yaitu Kesesuaian individu-organisasi, dan mampu mempengaruhi perilaku karyawan salah satunya kreativitas karyawan. Alasan ketiga, penelitian mengenai hubungan antara Kesesuaian individu-organisasi dan kreativitas masih jarang diteliti. Meskipun banyak penelitian yang ditujukan pada tema Kesesuaian individu-organisasi, namun masih sedikit yang memahami peran Kesesuaian individu-organisasi terhadap kreativitas karyawan (Jin, 2015). Hal ini cukup disayangkan meengingat pentingnya kreativitas karyawan, atau kinerja kreatif yang dilakukan oleh karyawan di lingkungan bisnis yang sangat kompetitif dan lingkungan tidak dapat diprediksi (Shalley dan Gilson, 2004).

Penelitian sebelumnya telah dilakukan penelitian mengenai hubungan kesesuaian individuorganisasi terhadap kreativitas karyawan pada segala bidang organisasi dan industri (Sarac et al., 2014), namun belum menyentuh pada objek kajian UMKM. Keberadaan Usaha mikro kecil dan menengah (UMKM) memegang peranan penting dalam perekonomian, baik dalam menyerap tenaga kerja, menyumbang devisa maupun kontribusinya dalam menyumbang pendapatan daerah dalam bentuk pajak (Darwanto, 2013). UMKM yang diteliti oleh peneliti dalam penelitian ini adalah UMKM bidang Konfeksi dimana kreativitas dapat berperan langsung bagi UMKM seperti pada hal desain, tehnik jahitan, kualitas bahan, dan lain lain

Tema kesesuaian individu-organisasi memang sudah sangat sering diteliti namun masih sedikit yang menguji peran Kesesuaian individu-organisasi terhadap kreativitas karyawan (Jin, 2015). Begitu juga perilaku kreatif, meskipun banyak penelitian yang mengidentifikasi mengenai pendorong dan penghalang perilaku kreatif, tetapi sedikit yang memberikan perhatian pada Kesesuaian individuorganisasi (Saraç et al., 2014). Hal tersebut dikarenakan beberapa peneliti menganggap bahwa kesesuaian individu-organisasi akan menciptakan perubahan dalam organisasi (Farabe, 2011), namun pendapat tersebut berbeda dengan hasil dari penelitian lain menunjukkan bahwa kesesuaian nilai antara individu dan lingkungan memiliki pengaruh positif terhadap perilaku kreatif dalam dimensi yang relevan (Leonora, 2012; Jin, 2015).

Menurut Chatman (1989) kesesuaian individuorganisasi didefinisikan sebagai kesesuian normanorma dan nilai-nilai organisasi dengan nilai-nilai individu karyawan. Pendapat lain mengatakan bahwa kesesuaian individu-organisasi merupakan pencocokan antara karakteristik individu karyawan 
dengan organisasi. Karakteristik individu terdiri dari ide-ide individu, prinsip, kepentingan, dan karakteristik organisasi terdiri dari doktrin organisasi, norma, tradisi, dan iklim organisasi secara keseluruhan (Hassan, 2012).

Hubungan positif antara PersonOrganisazation Fit dan kreativitas karyawan telah ditunjukkan didalam beberapa penelitian sebelumnya (Choi, 2004; Saraç et al., 2014; Jin, 2015). Hal tersebut didukung oleh Van Maanen and Schein (1979) yang menyatakan bahwa individu kreatif adalah karyawan yang memiliki tingkat kesesuaian nilai individu dan organisasi yang tinggi. Hal tersebut menjelaskan bahwa ketika karyawan memiliki tingkat kesesuaian antara nilai individu dan organisasi yang tinggi, maka akan mampu mendorong karyawan untuk memiliki perilaku yang kreatif dalam bekerja. Penelitian sebelumnya menemukan bahwa tingkat kesesuaian individu-organisasi (PersonOrganization Fit) memiliki hubungan yang positif terhadap kreativitas karyawan (Choi, 2004; Saraç et al., 2014; Jin, 2015). Berdasarkan hal tersebut, maka dapat disusun hipotesis sebagai berikut:

$\mathrm{H}_{1}$ : Person-organisazation fit berpengaruh positif signifikan pada kreatifitas

Selain adanya pengaruh dari tingkat kesesuaian individu-organisasi (Person-Organization Fit), kreativitas karyawan dapat didorong oleh komitmen organisasional yang dimilikinya. Komitmen organisasi adalah kemauan untuk melanjutkan pekerajaan dengan organisasi, setiap kepada organisasi untuk mngerahkan usaha ekstra dalam rangka mencapai tujuan organisasi, dan tingkat identifikasi karyawan dalam organisasi (Haq et al., 2014). Karyawan yang memiliki komitmen tinggi akan cenderung untuk memiliki keyakinan yang kuat dalam menerima tujuan organisasi dan memungkinkan untuk menunjukkan kinerja kreatif yang lebih baik. Hal tersebut didukung oleh beberapa penelitian sebelumnya yang menemukan adanya hubungan yang signifikan antara komitmen organisasi dan kreativitas (Sheikhy dan Farzan, 2015; Porrashidi dan Biglari, 2015; Sousa dan Coelho, 2011).

Komitmen organisasional merupakan faktor yang penting dalam kreativitas karyawan, karena seorang karyawan yang berkomitmen dan memiliki keyakinan kuat dengan nilai organisasi akan rela untuk berusaha ekstra untuk memenuhi tujuan organisasi, dan menunjukkan keinginan untuk mempertahankan keanggotaan organisasi (Sousa dan Coelho, 2011). Komitmen organisasional yang dimiliki karyawan akan mampu mendorong karyawan untuk lebih kreatif dalam bekerja, karena ketika karyawan berkomitmen maka karyawan akan akan memiliki keyakinan kuat dalam menerima tujuan organisasi dan memungkinkan untuk menunjukkan kinerja kreatif seperti memecahkan masalah dan menemukan ide yang bermanfaat bagi perusahaan dan tidak dimiliki oleh pesaing. Hal tersebut didukung oleh beberapa penelitian sebelumnya yang menemukan bahwa komitmen organisasi memiliki hubungan positif pada tingkat kreativitas kayawan (Hou et al., 2011). Sousa dan Coelho (2011) mengatakan bahwa karyawan yang berkomitmen pada pekerjaanya akan rela untuk berusaha lebih keras demi mencapai tujuan organisasinya. Berdasarkan hal tersebut, maka dapat disusun hipotesis sebagai berikut:

$\mathrm{H}_{2}$ : Komitmen berpengaruh positif signifikan pada kreatifitas

Tingkat kesesuaian individu-organisasi (PersonOrganization Fit) yang dimiliki karyawan akan mampu menciptakan komitmen karyawan ada pekerjaanya. Hal tersebut ditunjukkan didalam penelitian sebelumnya yang menyatakan bahwa tingkat kesesuaian individu-organisasi (PersonOrganization Fit) adalah prediktor bagi komitmen organisasional yang dimiliki karyawan (Karakurum, 2005) Sehingga karyawan yang memiliki tingkat kesesuaian antara individu dan organisasi akan berkomitmen dalam pekerjaanya. Komitmen organisasional yang dimiliki karyawan akan mampu mendorong karyawan untuk lebih kreatif dalam bekerja, karena ketika karyawan berkomitmen maka karyawan akan memiliki keyakinan kuat dalam menerima tujuan organisasi dan memungkinkan untuk menunjukkan kinerja kreatif seperti memecahkan masalah dan menemukan ide yang bermanfaat bagi perusahaan dan tidak dimiliki oleh pesaing. Hal tersebut menunjukkan bahwa, komitmen organisasional mampu mengarahkan kesesuaian antara individu dan organisasi (PersonOrganization Fit) menjadi suatu bentuk kreativitas karyawan. Sehingga, komitmen organisasional merupakan suatu variabel yang memiliki kemungkinan untuk memediasi hubungan kesesuaian individu-organisasi dan kreativitas karyawan. Berdasarkan hal tersebut, maka dapat disusun hipotesis sebagai berikut:

$\mathrm{H}_{3}$ : Person-organisazation fit berpengaruh positif signifikan pada komitmen organisasional

$\mathrm{H}_{4}$ : Person-organisazation fit berpengaruh positif signifikan pada kreativitas melalui komitmen organisasional sebagai mediasi. 


\section{METODE PENELITIAN}

Populasi dalam penelitian ini adalah karyawan UMKM konfeksi di Kabupaten Jepara sebanyak 923 karyawan. Agar sampel yang diperoleh representative rumus Slovin yaitu:

$$
\begin{aligned}
& n=\frac{923}{1+923(0.05)^{2}} \\
& n=\frac{923}{1+2,3075} \\
& n=279,06271 \\
& n=279
\end{aligned}
$$

Berdasarkan perhitungan menggunakan rumus Slovin maka jumlah sampel yang digunakan dalam penelitian ini adalah 279 responden. Teknik pengambilan sampel dalam penelitian ini menggunakan teknik simple random sampling. Demografi sampel dalam penelitian ini dapat dilihat pada Tabel .

Variabel dalam penelitian ini adalah Kesesuaian Individu-Organisasi (X1) yang meliputi empat indikator Kesesuaian Nilai, Kesesuaian Tujuan, Kesesuaian kepribadian dan karakteristik, Kesesuaian budaya.

Tabel 1. Demografi Jenis Kelamin

\begin{tabular}{cccc}
\hline No. & Jenis Kelamin & Frekuensi & Presentase \\
\hline 1. & Laki-laki & 120 & $43 \%$ \\
2. & Perempuan & 159 & $57 \%$ \\
\hline & Total & 279 & $100 \%$ \\
\hline
\end{tabular}

Sumber: Data primer diolah, 2017

Tabel 2. Demografi Usia

\begin{tabular}{cccc}
\hline Jumlahkelas & Interval Usia & Frekuensi & Presentase \\
\hline 1. & 16 tahun -19 tahun & 3 & $1 \%$ \\
2. & 20 tahun -23 tahun & 23 & $8 \%$ \\
3. & 24 tahun -27 tahun & 43 & $15 \%$ \\
4. & 28 tahun -31 tahun & 57 & $20 \%$ \\
5. & 32 tahun -35 tahun & 74 & $27 \%$ \\
6. & 36 tahun -39 tahun & 45 & $16 \%$ \\
7. & 40 tahun -43 tahun & 16 & $6 \%$ \\
8. & 44 tahun -47 tahun & 13 & $5 \%$ \\
9. & 48 tahun -53 tahun & 5 & $2 \%$ \\
\hline
\end{tabular}

Sumber: Data primer diolah, 2017

Tabel 3. Demografi Masa Kerja

\begin{tabular}{cccc}
\hline No. & Masa Kerja & Frekuensi & Presentase \\
\hline 1. & $2-4$ tahun & 99 & $35,4 \%$ \\
2. & $5-7$ tahun & 113 & $40,5 \%$ \\
3. & $8-10$ tahun & 54 & $19,4 \%$ \\
4. & $11-13$ tahun & 0 & $0 \%$ \\
5. & $14-16$ tahun & 1 & $0,4 \%$ \\
6. & $17-19$ tahun & 2 & $0,7 \%$ \\
7. & $20-22$ tahun & 1 & $0,4 \%$ \\
8. & $23-25$ tahun & 5 & $1,8 \%$ \\
9. & $26-29$ tahun & 4 & $1,4 \%$ \\
\hline & Total & 279 & $100 \%$ \\
\hline
\end{tabular}

Sumber: Data primer diolah, 2017 
Variabel Komitmen Organisasi (Y2) yang meliputi tiga dimensi yaitu Komitmen Afektif (Affective Commitment), Komitmen Berkelanjutan (Continuance Commitment), Komitmen Normatif (Normative Commitment) dengan total 10 indikator yang terdiri dari Komitmen Afektif 3 indikator, Komitmen Berkelanjutan 3 indikator, dan Komitmen Normatif 4 indikator. Variabel Kreativitas Karyawan (Y2) meliputi 9 indikator yaitu Menunjukan originalitas dalam pekerjaanya, mengambil resiko dalam menemukan ide baru dalam pekerjaanya, Menemukan kegunaan atau manfaat baru dari metode atau peralatan yang ada, Memecahkan masalah yang menimbulkan kesulitan lain, Mencoba ide dan pendekatan baru terhadap masalah, Mengidentifikasi peluang untuk produk/proses baru, Menciptakan kebaruan atau novelti ide yang berkaitan dengan pekerjaan, Memiliki peran baik dalam kreativitas, Menciptakan ide revolusioner dalam bidangnya.

Sebelum melakukan uji statistik, diperlukan pengujian alat ukur penelitian (Ghozali, 2013). Oleh karena itu, perlu dilakukan uji validitas dan uji reliabilitas. Uji validitas dilakukan dengan sampel sebanyak 279 responden, $\mathrm{df}=279-2=277$, maka $\mathrm{r}$ tabel $=0,1179$ (taraf signifikansi 5\%). Jika r-hitung $>$ r-tabel maka valid. Jika r-hitung < r-tabel maka tidak valid.

Pengolahan data dalam penelitian ini menggunakan program SPSS Versi 21. Hasil uji validitas terhadap variabel kesesuaian individuorganisasi, komitmen organisasi, dan kreativitas karyawan valid dengan tingkat signifikan kurang dari 0,05 atau r-hitung > r-tabel $(0,1179)$. Selain itu diperlukan uji reliabilitas untuk mengukur suatu kuesioner yang merupakan indikator dari variabel atau konstruk. Cronbach alpha (á) variabel dari penelitian ini $>0,70$ sehingga variabel dikatakan reliabel. Hasil uji reliailitas terhadap variabel kesesuaian individu-organisasi, komitmen organisasi, dan kreativitas reliabel dengan tingkat Cronbach's Alpha lebih besar dari 0,70.

\section{HASIL DAN PEMBAHASAN \\ Hasil Analisis Deskriptif Variabel Penelitian}

Analisis deskriptif digunakan untuk memberikan gambaran atau deskripsi empiris atas data yang dikumpulkan dalam penelitian. Analisis deskriptif yang digunakan dalam penelitian ini adalah kriteria tiga kotak (Ferdinand, 2014).

Berdasarkan analisis deskriptif yang telah dilakukan, rata-rata variabel kesesuaian individuorganisasi karyawan UMKM Konfeksi di Kabupaten Jepara secara keseluruhan dapat dilihat dari 4 indikator yaitu sebesar 82,08 yaitu termasuk dalam kriteria tinggi. Salah satu indikator kesesuaian individu-organisasi yang paling tinggi adalah kesesuaian nilai (indikator pertama).

Hal ini menunjukkan bahwa karyawan memiliki tingkat kesesuaian yang tinggi, hal tersebut dikarenakan karyawan tidak terikat secara resmi pada suatu UMKM karna tidak adanya sistem yang mengikat seperti kontrak kerja. Jadi, karyawan bebas berpindah ke UMKM Konfeksi yang sesuai dengan dirinya.

Berdasarkan analisis deskriptif yang telah dilakukan, rata-rata variabel komitmen organisasi pada karyawan UMKM Konfeksi di Kabupaten Jepara dapat dilihat dari 10 indikator yaitu sebesar 82,67 termasuk dalam kriteria tinggi. Berdasarkan hasil tersebut, terlihat rata-rata indikator komitmen organisasi menunjukkan hasil dengan kriteria tinggi, diantara indikator tersebut yang memiliki nilai tertinggi adalah indikator pertama yaitu 85,52 dimana karyawan merasa memiliki ikatan yang kuat dengan tempat dimana karyawan tersebut bekerja (indikator ke-1). Hal ini terjadi karena sebagaian besar UMKM Konfeksi di Kabupaten Jepara memiliki sistem kerja yang cenderung kearah kekeluargaan, dimana tidak ada tingkat kesenjangan yang signifikan antara karyawan dan pemilik usaha.

Tabel 4. Uji Hipotesis Parsial Kesesuaian Individu-Organisasi pada Kreativitas Karyawan.

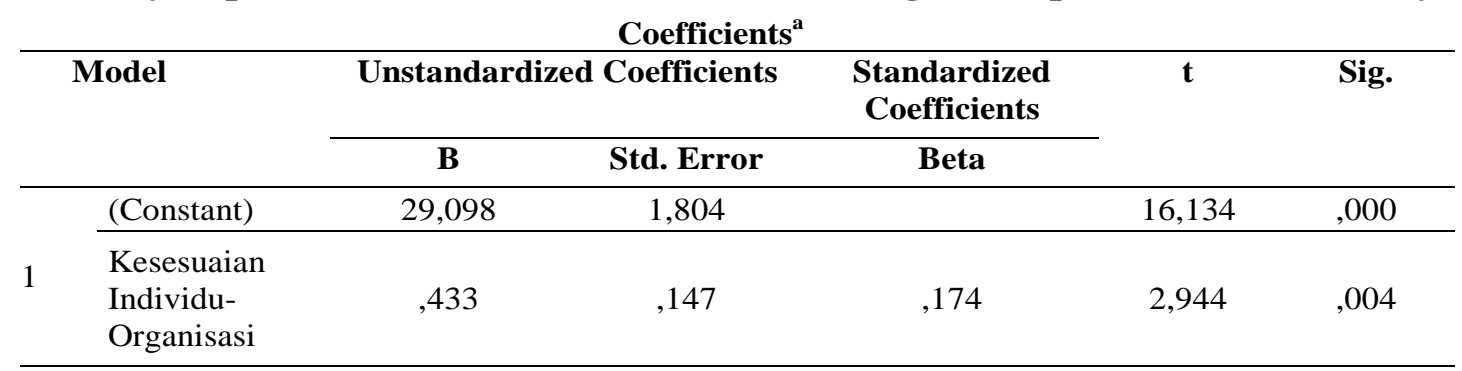

a. Dependent Variable: Kreativitas Karyawan

Sumber: Data primer diolah, 2017 
Berdasarkan analisis deskriptif yang telah dilakukan, hasil rata-rata pada variabel kreativitas karyawan UMKM di Kabupaten Jepara secara keseluruhan dapat dilihat dari 10 indikator yaitu sebesar 69,77 termasuk dalam kriteria sedang. Salah satu indikatornya, yaitu indikator dimana karyawan mempunyai ide baru yang lebih praktis untuk meningkatkan kinerja memperoleh nilai indeks sebesar 73,18 termasuk dalam kriteria tinggi. Hal ini menunjukkan bahwa karyawan memiliki ide-ide yang lebih praktis mengenai bagaimana cara meningkatkan kinerja.

Tabel 5. Uji Hipotesis Parsial Komitmen Organisasi pada Kreativitas Karyawan Coefficients $^{\mathrm{a}}$

\begin{tabular}{|c|c|c|c|c|c|c|}
\hline & \multirow[t]{2}{*}{ Model } & \multicolumn{2}{|c|}{$\begin{array}{l}\text { Unstandardized } \\
\text { Coefficients }\end{array}$} & \multirow{2}{*}{$\begin{array}{c}\begin{array}{c}\text { Standardized } \\
\text { Coefficients }\end{array} \\
\text { Beta }\end{array}$} & \multirow[t]{2}{*}{$\mathbf{t}$} & \multirow[t]{2}{*}{ Sig. } \\
\hline & & B & Std. Error & & & \\
\hline \multirow[b]{2}{*}{1} & (Constant) & 21,761 & 2,453 & & 8,871 & ,000 \\
\hline & $\begin{array}{l}\text { Komitmen } \\
\text { Organisasi }\end{array}$ & ,314 & ,061 & 296, & 5,161 & 000 \\
\hline
\end{tabular}

a. Dependent Variable: Kreativitas Karyawan

Sumber: Data primer diolah, 2017

Tabel 6. Uji Hipotesis Parsial Komitmen Organisasi pada Kreativitas Karyawan

\begin{tabular}{|c|c|c|c|c|c|c|}
\hline \multicolumn{7}{|c|}{ Coefficients $^{\mathrm{a}}$} \\
\hline \multirow{2}{*}{\multicolumn{2}{|c|}{ Model }} & \multicolumn{2}{|c|}{ Unstandardized Coefficients } & \multirow{2}{*}{$\begin{array}{c}\text { Standardized } \\
\text { Coefficients } \\
\text { Beta } \\
\end{array}$} & \multirow[t]{2}{*}{$\mathbf{t}$} & \multirow[t]{2}{*}{ Sig. } \\
\hline & & B & Std. Error & & & \\
\hline & (Constant) & 35,512 & 1,705 & & 20,830 & ,000 \\
\hline 1 & $\begin{array}{l}\text { Kesesuaian } \\
\text { Individu- } \\
\text { Organisasi }\end{array}$ & ,377 & 139 & 161 & 2,709 & ,007 \\
\hline
\end{tabular}

Tabel 7. Analisis Jalur Path : Regresi I.

Model Summary

\begin{tabular}{ccccc}
\hline Model & R & R Square & $\begin{array}{c}\text { Adjusted R } \\
\text { Square }\end{array}$ & $\begin{array}{c}\text { Std. Error of } \\
\text { the Estimate }\end{array}$ \\
\hline
\end{tabular}

\begin{tabular}{lllll}
\hline 1 &, $161^{\mathrm{a}}$ &, 026 &, 022 & 4,272 \\
\hline
\end{tabular}

a. Predictors: (Constant), Kesesuaian

Sumber: Data primer diolah, 2017

Coefficients $^{\mathrm{a}}$

\begin{tabular}{llccccc}
\hline Model & & Unstandardized Coefficients & $\begin{array}{c}\text { Standardized } \\
\text { Coefficients }\end{array}$ & t & Sig. \\
\cline { 3 - 6 } & & $\mathbf{B}$ & Std. Error & Beta & \\
\hline \multirow{2}{*}{1} & (Constant) & 35,512 & 1,705 & & 20,830 &, 000 \\
\cline { 2 - 6 } & Kesesuaian &, 377 &, 139 &, 161 & 2,709 &, 007 \\
\hline
\end{tabular}

a. Dependent Variable: Komitmen

mber: Data primer diolah, 2017 
Tabel 8. Analisis Jalur Path : Regresi II

Model Summary

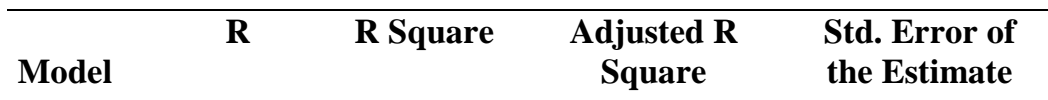

\begin{tabular}{lllll}
\hline 1 & $323^{\mathrm{a}}$ &, 104 &, 098 & 4,351 \\
\hline
\end{tabular}

a. Predictors: (Constant), Komitmen, Kesesuaian

Sumber: Data primer diolah, 2017

\begin{tabular}{|c|c|c|c|c|c|c|}
\hline \multicolumn{7}{|c|}{ Coefficients $^{\mathrm{a}}$} \\
\hline \multirow[t]{2}{*}{ Model } & & \multicolumn{2}{|c|}{ Unstandardized Coefficients } & \multirow{2}{*}{$\begin{array}{c}\begin{array}{c}\text { Standardized } \\
\text { Coefficients }\end{array} \\
\text { Beta }\end{array}$} & \multirow[t]{2}{*}{$\mathrm{t}$} & \multirow[t]{2}{*}{ Sig. } \\
\hline & & B & Std. Error & & & \\
\hline \multirow{3}{*}{1} & (Constant) & 18,732 & 2,782 & & 6,733 & ,000 \\
\hline & Kesesuaian & 323 &, 144 &, 130 & 2,251 &, 025 \\
\hline & Komitmen & ,292 & ,061 & 275 & 4,769 &, 000 \\
\hline
\end{tabular}

a. Dependent Variable: Kreativitas

Sumber: Data primer diolah, 2017

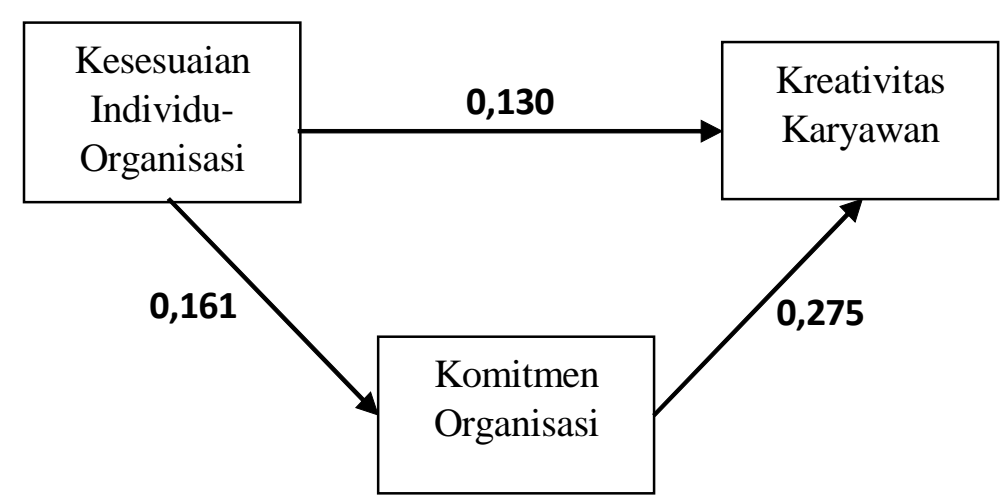

Gambar 1. Uji Mediasi

Pengaruh Kesesuaian Individu-Organisasi Pada Kreativitas Karyawan pada Karyawan Umkm di Bidang Konfeksi di Kabupaten Jepara.

Hasil penelitian ini menjukkan bahwa kesesuaian individu-organisasi berpengaruh signifikan terhadap kreativitas karyawan UMKM konfeksi di Kabupaten Jepara. Hasil dapat diketahui dari uji statistik yang telah dilakukan diperoleh thitung sebesar 2,944 yang lebih besar dari nilai t tabel, dan diperoleh sig. 0,004 > 0,05 yang artinya kesesuaian nilai individu organisasi memiliki pengaruh signifikan pada komitmen organisasi.

Terdukungnya hipotesis pertama menunjukkan bahwa adanya hubungan positif dan signifikan antara kesesuaian individu-organisasi dan kreativitas karyawan. Hal tersebut dapat diartikan bahwa semakin tinggi tingkat kesesuaian antara nilai individu dengan nilai organisasi yang dimiliki karyawan maka karyawan akan semakin kreatif dalam meyelesaikan pekerjaanya. Sebaliknya Sebaliknya jika kesesuaian individu-organisasi yang dimiliki karyawan rendah maka karyawan cenderung memiliki kreativitas yang rendah dalam pekerjaanya. Hasil penelitian ini sesuai dengan penelitian terdahulu yang menyatakan bahwa kesesuaian individu-organisasi berpengaruh positif pada kreativitas karyawan (Thomas, 2013, Jin, 2015, Leonora, 2012, Sarac, 2014).

Hasil penelitian ini juga mendukung teori dari Kristof, (1996) dimana kesesuaian atau kecocokan antara karyawan dan organisasi ketika salah satu pihak menyediakan kebutuhan pihak yang lain, dan kedua pihak memiliki karakteristik fundamental yang sama. Karyawan akan merasa nyaman dalam bekerja jika organisasi tempat karyawan tersebut bekerja memiliki kesesuaian nilai yang cukup tinggi dengan diri individu. Ketika karyawan nyaman dengan organisasi tersebut maka karyawan akan 
mampu bekerja dengan optimal dengan seluruh potensi yang dimiliki, karyawan akan mampu mengeluarkan kinerja terbaiknya sehingga akan mendorong karyawan untuk menemukan gagasan atau ide baru yang bermanfaat dalam mengerjakan atau menyelesaikan pekerjaanya yang akan menjadi awal dari inovasi dalam organisasi (Farabee, 2011). Inovasi dalam organisasi tidak mudah untuk ditiru oleh pesaing karena ide atau gagasan yang lahir merupakan hal yang unik dan baru dan hal tersebut akan menjadi keunggulan kompetitif yang dimiliki organisasi.

\section{Pengaruh Kesesuaian Individu-Organisasi Terhadap Komitmen Organisasi Pada Karyawan Umkm Di Bidang Konfeksi Di Kabupaten Jepara.}

Hasil penelitian ini menjukkan bahwa kesesuaian individu-organisasi berpengaruh signifikan terhapad komitmen organisasi karyawan UMKM konfeksi di Kabupaten Jepara. Hasil dapat diketahui dari uji statistik yang telah dilakukan diperoleh $t$ hitung sebesar 2,709 yang lebih besar dari nilai t tabel, dan diperoleh sig. 0,007 > 0,05 yang artinya kesesuaian nilai individu organisasi memiliki pengaruh signifikan pada komitmen organisasi.

Terdukungnya hipotesis kedua menunjukkan bahwa adanya hubungan positif dan signifikan antara kesesuaian individu-organisasi dan komitmen organisasi. Hal tersebut dapat diartikan bahwa semakin tinggi tingkat kesesuaian antara nilai individu dengan nilai organisasi yang dimiliki karyawan maka karyawan akan memiliki keinginan yang semakin kuat untuk tetap menjadi anggota organisasi, berusaha keras sesuai keinginan organisasi, serta memiliki keyakinan dan mampu menerima nilai dan tujuan organisasi. Sebaliknya jika kesesuaian individu-organisasi yang dimiliki karyawan rendah maka karyawan cenderung memiliki komitmen organisasi atau keterikatan dengan organisasi yang rendah. Hasil penelitian ini sesuai dengan penelitian terdahulu yang menyatakan bahwa kesesuaian individu-organisasi berpengaruh positif pada komitmen organisasi yang dimiliki kayawan (Saleem et al., 2011; Dimaculangan dan Aguiling, 2012; Ahmadi et al., 2014; dan Khaola dan Sebotsa, 2015).

Berdasarkan konsep yang dikemukakan oleh Sutarjo, (2011), bahwa salah satu cara mengelola kesusian individu-organisasi adalah dengan proses seleksi yang tepat. Dalam proses pemilihan karyawan perusahaan harus selektif untuk mendapatkan karyawan yang baik dalam bekerja dan tidak meninggalkan organisasi sewaktu-waktu. Selama proses seleksi karyawan, perusahaan perlu memahami kesesuaian individu-organisasi antara kedua belah pihak, agar mendapatkan karyawan yang memiliki pengetahuan, ketrampilan, dan kemampuan sesuai. Mencari calon yang memiliki potensi dibutuhkan pendekatan yang lebih fleksibel dan komprehensif.

\section{Pengaruh Komitmen Organisasi Terhadap Kreativitas Pada Karyawan Umkm Di Bidang Konfeksi Di Kabupaten Jepara}

Hasil penelitian ini menjukkan bahwa komitmen organisasi berpengaruh signifikan terhadap keativitas karyawan UMKM konfeksi di Kabupaten Jepara. Hasil dapat diketahui dari uji statistik yang telah dilakukan diperoleh thitung sebesar 5,161 yang lebih besar dari nilai t tabel, dan diperoleh sig. 0,000 > 0,05 yang artinya kesesuaian nilai individu organisasi memiliki pengaruh signifikan pada komitmen organisasi.

Terdukungnya hipotesis ketiga menunjukkan bahwa adanya hubungan positif dan signifikan antara komitmen organisasi dan kreativitas karyawan. Hal tersebut dapat diartikan bahwa semakin tinggi komitmen organisasi yang dimiliki maka karyawan akan perilaku yang lebih kreatif dalam bekerja sehingga karyawan akan mampu menyelesaikan pekerjaan dengan lebih efektif dan efisien. Sebaliknya jika komitmen organisasi yang dimiliki karyawan rendah maka karyawan cenderung memiliki perilaku yang kurang kreatif dalam bekerja dan tidak mampu bekerja secara lebih efisien dan efektif. Hasil penelitian ini sesuai dengan penelitian terdahulu yang menyatakan bahwa komitmen organisasi memiliki hubungan positif pada kreativitas karyawan (Wang dan Netemeyer, 2004, Sheiky dan Farzan, 2015; Porrasidhi dan Biglari, 2015; Sousa dan Coelho, 2011).

Komitmen organisasional adalah faktor yang penting dalam kreativitas karyawan, karena seorang karyawan yang berkomitmen dan memiliki keyakinan kuat dengan nilai organisasi akan rela untuk berusaha ekstra untuk memenuhi tujuan organisasi, dan menunjukkan keinginan untuk mempertahankan keanggotaan organisasi (Sousa dan Coelho, 2011). Merujuk pada konsep komitmen menurut Meyer et al. (2002), komitmen organisasi mencerminkan tingkatan dimana seseorang mengenali sebuah organisasi dan terikat pada tujuan-tujuannya. Komitmen organisasi adalah sikap kerja yang penting karena orang-orang yang memiliki komitmen diharapkan bisa menunjukkan kesediaan untuk 
bekerja lebih keras demi mencapai tujuan organisasi dan memiliki hasrat yang lebih besar untuk tetap bekerja dalam suatu perusahaan. Seorang karyawan yang berkomitmen akan cenderung membalas atasanya (Ackfeldt dan Coote, 2005) dengan cara berperan untuk kesejahteraaan organisasi, dan memungkinkan untuk ikut terlibat dalam kreativitas, seperti kreatif dalam kinerjanya (Wang dan Netemeyer, 2004) yang kemudian menjadi kemudian kinerja organisasi.

\section{Pengaruh Kesesuaian Individu-Organisasi Terhadap Kreativitas Karyawan Melalui Komitmen Organisasi Pada Karyawan Umkm Di Bidang Konfeksi Di Kabupaten Jepara.}

Hasil penelitian menunjukkan bahwa komitmen organisasi mampu memediasi hubungan antara kesesuaian individu-organisasi dan kreativitas karyawan UMKM konfeksi di Kabupaten Jepara. Hasil dapat diketahui dari uji statistik yang telah dilakukan dan menunjukkan hubungan langsung kesesuaian individu-organisasi lebih kecil dibandingkan dengan hubungan tidak langsung kesesuaian individu-organisasi pada kreativitas karyawan melalui komitmen organisasi sebagai variabel pemediasi 0,174>0,130. Dari hasil tersebut dapat disimpulkan bahwa pengaruh kesesuaian individu-organisasi terhadap kreativitas karyawan akan lebih besar jika melalui komitmen organisasi sebagai variabel pemediasi.

Dalam penelitian sebelumnya terdapat perbedaan pendapat mengenai pengaruh kesesuaian individu-organisasi pada kreativitas karyawan. Hal tersebut juga menjadi pertimbangan peneliti dalam menambahkan variabel komitmen organisasi sebagai pemediasi. Pada penelitian terdahulu disarankan agar menambahkan variabel mediasi yang memiliki kemungkinan mempengaruhi hubungan antara kesesuaian individu-organisasi dan kreativitas karyawan karena adanya dugaan bahwa budaya juga mempengaruhi hubungan tersebut (Sarac et al., 2014). Komitmen organisasi juga telah banyak diteliti mengenai hubunganya dengan kreativitas karyawan, dan menghasilkan hubungan yang positif. Selain itu kesesuaian individu-organisasi juga menjadi variabel yang mampu memprediksi adanya komitmen organisasi (Karakurum, 2005). Melihat keterkaitan variabel tersebut, sangat dimungkinkan jika komitmen organisasi yang memiliki hubungan dengan variabel kesesuaian individu-organisasi dan kreativitas karyawan menjadi variabel yang mampu memediasi hubungan tersebut.

\section{SIMPULAN DAN SARAN}

Simpulan dalam penelitian ini adalah kesesuaian individu-organisasi berpengaruh positif pada kreativitas karyawan. Hal ini menunjukkan bahwa semakin tinggi tingkat kesesuaian individu-organisasi maka tingkat kreativitas karyawan akan semakin tinggi. Temuan lain menunjukkan bahwa hubungan antara kesesuaian individu-organisasi mampu dimediasi oleh komitmen organisasi, dimana komitmen organisasi merupakan variabel yang menjadi variabel prediktor bagi kreativitas karyawan, dan kesesuaian individu-organisasi merupakan variabel prediktor bagi komitmen organisasi.

Adapun saran yang dapat peneliti berikan pada organisasi atau dalam hal ini adalah UMKM konfeksi di Kabupaten Jepara sebaiknya mengadakan sosialisasi yang intensif dalam bentuk sebuah pertemuan dimana pemilik usaha menjelaskan secara langsung pada karyawan mengenai nilai-nilai dan budaya yang dimiliki oleh oranisasi. Selain itu organisasi hendaknya membuat sistem kerja yang mampu mengikat karyawan. Nilai indeks terendah pada komitmen organisasi terdapat pada indikator dimana karyawan merasa organisasi berhak mendapatkan kesetiaanya yaitu sebesar $77,56 \%$, hal tersebut karena tidak adanya sistem kerja yang mengikat karyawan merasa ragu untuk memberikan kesetiaanya karena tidak adanya kepastian mengenai kerjasama di masa depan. Pihak pemilik unit usaha perlu mengadakan sesi diskusi yang terbuka bagi semua karyawan untuk mengutarakan ide serta pendapatnya. Pada variabel kreativitas karyawan indeks frekuensi terendah terdapat pada indikator dimana karyawan menunjukan originalitas dalam pekerjaanya dan menciptakan ide revolusioner dalam bidangnya yaitu sebesar $66,88 \%$. Hal tersebut karena karyawan terpaku pada standar yang ditetapkan oleh organisasi sehingga hasil pekerjaan karyawan sama dengan yang lainya dan kurangnya pengetahuan serta kesempatan untuk menunjukkan gagasan dimiliki karyawan UMKM konfeksi di Kabupaten Jepara. Dengan adanya sesi diskusi akan memberikan peluang bagi karyawan menunjukkan kreativitasnya serta menambah wawasan atau pengetahuan dengan berbagi informasi serta pengalaman dengan yang lain.

Peneliti selanjutnya hendaknya dapat meneliti pada skala yang lebih luas dan bidang yang lebih beragam. Dengan demikian penelitian tersebut dapat memberikan gambaran yang lebih spesifik mengenai pengaruh kesesuaian individu-organisasi dan komitmen organisasi pada kreativitas karyawan. 
Selain itu penelitian selanjutnya juga disarankan untuk menggunakan variabel lain selain komitmen organisasi sebagai mediator seperti variabel perilaku kerwargaan organisasional. Hal tersebut dikarenakan ketika karyawan memiliki perilaku kewargaan organisasional yang tinggi akan dengan sukarela berbuat lebih bagi organisasi meskipun tanpa adanya tuntutan dari organisasi maupun diakui sistem imbalan formal yang berlaku didalam organisasi sehingga akan memicu karyawan untuk berkreasi bagi organisasi. Hal tersebut juga disarankan oleh penelitian sebelumnya (Sarac et al., 2014:495).

\section{REFERENSI}

Ackfeldt, A., dan Coote, L. V. 2005. A study of Organizational Citizenship Behaviors In A Retail Setting. Journal Of Business Research, 58, 151-159.

Ahmadi, S. A. A., Mohammadpour, B., Rajabi, M dan Baghbani, F. 2014. Effect of PersonOrganization Fit on Organizational Commitment. International Journal of Information Technology and Management Studies, 1(1) : 33-43.

Allen, N. J., dan Meyer, J. P. 1990. The Measurement And Antecedents Of Affective, Continuance And Normative Commitment To The Organization. Journal Of Occupational Psychology, 63, 1-18.

Ambita. 2013. Pengaruh Pendidikan, Pelatihan, Dan Pembinaan Sumber Daya Manusia Terhadap Kinerja Pegawai. Management Analysis Journal, 2(2), 1-6.

Barney, J. 1991. Firm Resources And Sustained Competitive Advantage. Journal of Management, 17(1), 99-120.

Becker, B., dan Gerhart, B. 1996. The Impact Of Human Resource Management On Organizational Performance/ : Progress And Prospects. The Academy Of Management Journal, 39(4), 779-801.

Cable, D. M., dan Judge, T. A. 1995. The Role Of Person-Organization Fit In Organizational Selection Decisions The Role Of PersonOrganization Fit In Organizational Selection.

Cable, D. M., dan Parsons, C. K. 2001. Socialization Tactics And Person-Organization Fit. Personnel Psychology, 54(1), 1-23.

Chatman JA. 1989. Improving Interactional Organizational Research: A Model of PersonOrganization Fit. The Academy of Management Review, 14(3):333-349.
Chen, M. Y., Shui, Y., Vicky, W., Chen, M. Y., Wang, Y. S., dan Sun, V. 2012. Intellectual Capital And Organizational Commitment Evidence From Cultural Creative Industries In. Personnel Review, 41(3), 321-339.

Cheung, M. F. Y., dan Wong, C. 2011. Transformational Leadership, Leader Support, And Employee Creativity. Leadership dan Organization Development Journal, 32(7), 656-672.

Collins, J., dan Porter, M. E. 1985. Strategy And Competitive Advantage. New York: Free Press.

Darwanto, dan Tri Utami. 2013. Pengembangan Usaha Mikro Kecil dan Menengah (UMKM) Berbasis Ekonomi Kreatif di Kota Semarang. Diponegoro Journal of Ecomomics. 2(4) 113

Dimaculangan, E. D dan Aguiling, H. M. 2012. The Effects of Transformational Leadership on Salespersons Turnover Intention. International Journal of Business and Social Science. 3 (19) : 197-210.

Edwards, J. R. 2008. Person-Environment Fit In Organizations: An Assessment Of Theoretical Progress. The Academy Of Management Annals, 2(1), 167-230.

Faizan, A. 2014. Pengaruh Kreativitas Iklan Dan Endorser Terhadap Proses Keputusan Pembelian Konsumen Mie Sedaap. Management Analysis Journal, 3(2), 1-8.

Farabee, A. M., dan M. 2011. Person-Organization Fit As A Barrier To Employee Creativity.

Ferdinand, A. 2014. Metode Penelitian Manajemen. Semarang: Badan Penerbit Universitas Diponegoro.

Ghoniyah, N., dan Masurip. 2011. Peningkatan Kinerja Karyawan Melalui Kepemimpinan, Lingkungan Kerja Dan Komitmen. Jurnal Dinamika Manajemen, 2(2), 118-129.

Ghozali, Imam. 2013. Aplikasi Analisis Multivariate dengan Program IBM SPSS 21 Update PLS Regresi (Cetakan ke-7). Badan Penerbit Universitas Diponegoro: Semarang.

Handriani, E. 2011. Analisis Faktor Daya Saing Di Kabupaten Semarang. Jurnal Dinamika Manajemen, 2(1), 17-25.

Hou, Y., Gao, G., Wang, F., Li, T., dan Yu, Z. 2011. Organizational Commitment and Creativity/: the Influence of thinking styles. Annals of Economics and Finance, 12(2), 411-431.

Jin, S. 2015. The Relationship Between PersonOrganization Fit And Employee Creativity: The 
Mediating Role Of Creative Capital. Business And Management Research, 4(3), 24-31.

Judge A., T., dan Cable M., D. 1996. PersonOrganization Fit, Job Choice, And Organization Entry. Organizational Behavior And Human Decision Processes, 67(3), 204-213.

Karakurum, M. 2005. The Effects Of PersonOrganization Fit On Employee Job Satisfaction, Performance And Organizational Commitment In A Turkish Public Organization. Retrieved From Http://Www.Spk.Gov.Tr/ Displayfile.Aspx?Action=Displayfiledan Pageid $=744 \mathrm{danFn}=744$.Pdf

Khaola, P. P dan Sebotsa, T. 2015. PersonOrganization Fit, Organisational Commitment and Organisational Citizenship Behaviour. Danish Journal of Management and Business Sciences. 1 (3) : 67-74.

Kristof-Brown, A. L., Zimmerman, R. D., dan Johnson, E. C. 2005. Consequences Of Individuals Â€ $€^{T m}$ Fit At Work/ : A MetaAnalysis Of Person-Jo.

Kristof, A. L. 1996. Person-Organization Fit: An Integrative Review Of Its Conceptualizations, Measurement, And Implications. Personnel Psychology, 49(1), 1-49.

Leonora, M.C. 2012. "Adaptation and creativity in cultural context". Psicologý'a, 30(1), pp. 3-18.

Porrashidi, R., dan Biglari, M. 2015. Explaining The Relationship Between Organizational Culture, Organizational Commitment And Employee S ' Creativity Among Employees Of Fars Province Telecommunication Company In 2015 Abstract/ : Introduction/: Managem, 1(1), 139-147.

Putri, V. W., dan Yuniawan, A. 2016. Organizational Effectiveness/: Social Capital And Efektifitas Organisasi/ : Pendekatan. Jurnal Dinamika Manajemen, 7(1), 76-90.

Runco, M. A. 2004. Key Words Divergent Thinking, Ideation, Originality, Flexibility, Domains Of Performance, Implicit Theories, Problem Finding. Psychology Department, 55, 657687.

Saraç, M., Efil, I., dan Eryilmaz, M. 2014. A Study Of The Relationship Between PersonOrganization Fit And Employee Creativity. Management Research Review, 37(5), 479501.
Saleem, W. A., Adnan, G dan Ambreen, M. 2011. Person-Organization, Organizational Commitment and Knowledge Sharing Attitude-An Analytical Study. Information Management and Business Review. 3 (2):110-116.

Shalley, C. E., dan Gilson, L. L. 2004. What Leaders Need To Know/ : A Review Of Social And Contextual Factors That Can Foster Or Hinder Creativity, 15, 33-53.

Shalley, C. E., Zhou, J., dan Oldham, G. R. 2004. The Effects Of Personal And Contextual Characteristics On Creativity: Where Should We Go From Here? Journal Of Management, 30(6), 933-958.

Sheikhy, A., dan Farzan, F. 2015. Explaining The Relationship Between Employees ' Personal values, creativity, organizational commitment and customer oriented in Pasargad Bank branches. Journal of Scientific Research and Development 2, 2(7), 218-225.

Sousa, C. M. P., dan Coelho, F. 2011. From Personal Values to Creativity: Evidence from Frontline Service Employees. European Journal of Marketing, 45(7/8), 1029-1050.

Sutarjo. 2011. Ten Ways of Managing PersonOrganization Fit (PO-Fit) Effectively: A Literature Study. International Journal of Business and Social Science. 2 (2) : 226-233.

Thomas, T. P. 2013. The Effect of Personal Values, Organizational Values, and Person-Organization Fit on Ethical Behaviors and Organizational Commitment Outcomes among Substance Abuse Counselors/: A Preliminary Investigation.

Tugal, F. N., dan Kilic, K. C. 2015. PersonOrganization Fit/ : It's Relationships with Job Attitudes and Behaviors of Turkish Academicians. International Review of Management and Marketing, 5(4), 195-202.

Wang, G., dan Netemeyer, R. G. 2004. Salesperson creative performance: Conceptualization, measurement, and nomological validity. Journal of Business Research, 57(8), 805-812.

Zhou, J., dan Shalley, C. E. 2003. Research On Employee Creativity: A Critical Review And Direction For Future Research. Research in Personnel and Human Resources Management, 22, 165-217. 